\title{
E-Government Transformation in Tanzania: Status, Opportunities, and Challenges
}

\author{
Emmanuel Constantine Lupilya* and Kwangho Jung**
}

\begin{abstract}
This study examined the status, challenges, and opportunities for egovernment transformation in Tanzania. The study begins by examining the status, challenges, and opportunities of e-government as a potential driver of government transformation. Expert survey results and a SWOT analysis were applied to analyzing the current challenges critical to the initiation, development, and implementation of e-government in Tanzania. Data were collected from Tanzania from May to June 2014 using a focus group discussion and field observations as well as a documentary review. The three factors of technology, social e-transformation, and institutional docility were discussed to see whether they positively or negatively affect e-government transformation. The study found that (1) a reluctance towards transparency and accountability, (2) an avalanche of technology, and (3) an illusion of innovation and technological misfortune led to a stagnant e-government process, yielding more corruption and conflict of competing interests in the whole transformation process. These problems substantially affect technology and social e-transformation whereas institutions become more docile. From the e-government Master Plan to technology policy instruments, including IT/ICT infrastructure policy, information and data privacy and confidentiality, and cybercrimes policy were amongst the most critical challenges. An implication for the successful institutionalization of e-government transformation is that leadership should strategically embrace developing sustainability, planning, coordination, optimization, and integration of IT/ICT infrastructure projects for the betterment of e-government transformation.
\end{abstract}

Keywords: e-government, ICT Technology, Social e-Transformation, Tanzania, institutions

* Emmanuel Constantine Lupilya is a government official working in the Office of the President of Tanzania. He holds a Bachelor's Degree in Business Administration, a Master's of Science in Information Technology obtained from Finland, a Master's Degree in e-government and e-policy from Seoul, Korea. He is currently a Doctoral Candidate in the Graduate School of Public Administration at Seoul National University. His research interests include e-government, e-government policy, public policy, technology inequality, and e-government transformation in developing countries. E-mail: elupilya@gmail.com.

** Kwangho Jung is a Professor of the Graduate School of Public Administration at Seoul National University. He is also a Research Affiliate of the Korea Institute of Public Affairs of Seoul National University. His research focuses on health policy instruments, cabinet ministers, and government trust. Dr..Jung is the corresponding author of this article. E-mail: kwjung77@snu.ac.kr.

Manuscript received February 12, 2015; out for review March 21, 2015; review completed April 8, 2015; accepted April 16, 2015.

The Korean Journal of Policy Studies, Vol. 30, No. 1 (2015), pp. 147-184.

(C) 2015 by the GSPA, Seoul National University 


\section{INTRODUCTION}

E-government in Tanzania faces two challenges: (1) whether or not to ensure that government must become mobile, responsive, efficient and effective in all spheres of its conduct; and (2) whether or not to provide equitable and high quality service to its citizens (Heeks, 1998, 2001; Coleman, 2006; Kumar et al., 2007). In order to satisfy these two conditions, the government should play an appropriate role in creating a sound environment that allows free access to online information, interactions, trade, and in building a strong and free internet communications platform. However, innovative design and implementation (Heeks, 2001; Ngulube, 2007) of such a "free online" environment is a somewhat challenging and speculative task, especially for developing and underdeveloped countries. It follows that the mystification of understanding egovernment as applied in government institutions is still a paradox for a number of reasons: among of them is the ever-growing speed of internet technology, connectivity, transmission, accessibility, and sharing of online data and information by consumers (citizens, business, and governments). Outdated ICT and telecommunications policies, absence of legal enforcement of online interactions, ICT regulations and e-government strategies continue to burden the government in terms of internet technologies, IT pricing, and related infrastructure. This has made private institutions (IT and telecommunications industries) experience this as a gateway to skyrocketing their revenue though pricing. Other miscellaneous charges are applied depending on the services include but are not limited to service level agreement charges, polling charges, bandwidth monitoring charges, and monthly service charges. The researcher found that, even internet access, sharing and transferring information, and data cause another serious institutional challenge in terms of managing online protections, data privacy, information confidentiality, and institutional accountability.

Remarkably, data or information confidentiality is of particular concern whether at a government, private sector, collective or individual citizen level. Along with that line of thought, e-government services should not be seen as a luxury technology but part of the infrastructure for day-to-day living in Tanzania. For instance, government leaders (top, middle, and bottom), local IT / ICT experts (government and private institutions), educational sectors (schools, vocational training, colleges and universities, etc.) and the citizens (bloggers, social media networks, IT think-tank groups, individuals, etc.) must together embrace the use of the internet and support government initiatives directed towards making e-government part and parcel of their communication routines. Recent studies (Ndou, 2004; Heeks, 2006; Kumar et al., 2007) have also highlighted problems that amount to the failure of e-government. These studies argue e-government projects will always fail in the absence of a strategic e-government plan as well as of 
institutions for administering the national e-government project. All these are significant issues in Tanzanian e-government.

Various actors from government institutions to the private sector, from the citizenry to individuals are currently struggling to embrace the culture shift from locked control information to more sharing and interacting online. In addition, government institutions must have virtuous leaders capable of establishing and leading an e-Government Institutional Research and Development Center (eIR\&D) to tackle rising online challenges. Furthermore, for the interest of the nation, government should focus on developing an e-government master plan and on building a strong local data center (LDC). Otherwise, any delay in such efforts may lead the government to fail to utilize e-government, provide equitable online services, and fight against cybercrimes emanating on the internet or other complex online networks (Heeks, 2002; 2003). This requires clean institutional processes for strictly defining who is accountable for designing, maintaining, and ensuring "Privacy and Confidentiality," which institutions are responsible in the implementation process, which institutions are responsible for monitoring and evaluation and who is accountable for feedback, and the framework for checks and balances. All these still remain key issues that pose a serious challenge in Tanzania (Heeks, 1999; Fountain, 2001; Ciampa, 2010; Mutula and Masters 2010).

Additionally, at the stage of information publishing (internet, web, data, information, application software, blogs, etc.) customers must be properly guided to trust universal services delivered online. Along with social e-transformation, social group, individuals, and e-transformation organizations are the key drivers for creating e-government services. While the study views institutions (national security agency, other government and e-government institutions and institutions in the private and non-profit sectors) as continuing to become docile to donors, a virtuous leader who will define a new approach must be installed in order to harness national efforts and direct them towards the e-government project (Coursey and Norris, 2008; Adeyemo, 2011).

The main concern of this study is analyzing these pertinent issues of the status, challenges to, and prospects for e-government in Tanzania. This study focuses on: (1) examining the challenges to e-government in Tanzania; (2) exploring the opportunities for e-government in Tanzania; and (3) suggesting a future framework for e-government transformation in Tanzania. The second section of the article provides environmental and institutional backgrounds of e-government in underdeveloped countries, especially in the context of Tanzania, and reviews the relevant literature. The third section discusses results of the expert survey and the SWOT analysis. The last section summarizes various empirical results from focused group interviews and the expert survey, and suggests policy implications and recommendations for future research. 


\section{LITERATURE REVIEW AND CURRENT E-GOVERNMENT ISSUES IN TANZANIA}

\section{The “Cozy Paradox" of E-Government Concepts}

The emergence of e-government concepts has recently become too abstract for the general public and government candidates to understand it. In terms of economy, egovernment can be understood as a tool to reduce cost, increase efficiency, and enhance productivity (Heeks, 1998, 2001; 2002; Kumar et al, 2007; Yonazi, 2010). The definitions can be summarized in Table 1 .

Table 1. Definitions of E-Government

\begin{tabular}{|c|c|c|c|}
\hline \multirow{2}{*}{ AUTHORS } & \multirow{2}{*}{ CONCERNED WITH: } & \multicolumn{2}{|c|}{ FOCUSING ON: } \\
\hline & & Transformation & Improved Service \\
\hline $\begin{array}{l}\text { Hernon (cited in Duffy, } \\
\text { 2000) }\end{array}$ & $\begin{array}{l}\text { Simply using information } \\
\text { technology to deliver government } \\
\text { services directly to the customer } \\
\text { 24/7. The customer can be a } \\
\text { citizen, a business, or even } \\
\text { another government entity }\end{array}$ & & $\begin{array}{l}\text { To deliver } \\
\text { government services }\end{array}$ \\
\hline UN \& ASPA, (2002: 1) & $\begin{array}{l}\text { "Using the Internet and the } \\
\text { World-Wide-Web for delivering } \\
\text { government information and } \\
\text { services to citizens" }\end{array}$ & & \\
\hline Kumar et al. (2007) & $\begin{array}{l}\text { Basically, as a tool to improve } \\
\text { services to all (G2C, G2B, G2G) }\end{array}$ & & \\
\hline $\begin{array}{l}\text { DiCaterino \& Pardo } \\
\text { (1998) }\end{array}$ & $\begin{array}{l}\text { E-government as more concerned } \\
\text { with interactivity and service } \\
\text { delivery from a bigger perspective }\end{array}$ & & \multirow{3}{*}{$\begin{array}{l}\text { Efficiency and } \\
\text { effectiveness; } \\
\text { Accountability; } \\
\text { Interactivity }\end{array}$} \\
\hline Ho (2002) & $\begin{array}{l}\text { A paradigm shift in government } \\
\text { through enhancing accountability }\end{array}$ & & \\
\hline Heeks (1998) & $\begin{array}{l}\text { Enhancing government efficiency } \\
\text { and effectiveness }\end{array}$ & & \\
\hline Coleman (2006) & $\begin{array}{l}\text { E-government as automated } \\
\text { procedures and interaction for } \\
\text { sharing the flow of information } \\
\text { services through the internet for } \\
\text { well "balanced e-government" }\end{array}$ & & $\begin{array}{l}\text { Balanced } \\
\text { e-government }\end{array}$ \\
\hline
\end{tabular}




\section{The Current Status of E-Government}

Looking at the first stage of information technology and its challenges, the study examines the current status of e-government development in Tanzania using the UN technological perspective. Table 2 and Table 3 show a drop from $35 \%$ to $29 \%$ from 2012 to 2014 in the case of Tanzania. The trend is attributed to the lack of systematic integration of web platforms offering potential services to a wider range of customers (see Table 8). In addition, this can explain the weakness of not building a systematic infrastructure to harness the potential of information technology. For instance, Tanzania is below average, at about $8 \%$, in terms of telecommunications infrastructure (Table 3) with no progress in infrastructure development. Likewise, e-participation was also below average at $8 \%$ in 2012 but shot incredibly to 39\% in 2014. Both of these indicators have indicated a relatively low level of progress in e-government implementation in Tanzania.

Table 2. Extent of E-service Delivery Stages in Tanzania

\begin{tabular}{|c|c|c|c|c|c|c|c|c|c|c|}
\hline \multirow{3}{*}{\begin{tabular}{l}
\multicolumn{1}{c}{ Components } \\
STAGES OF \\
E-GOVERNMENT
\end{tabular}} & \multicolumn{10}{|c|}{ Percent Utilization } \\
\hline & \multicolumn{5}{|c|}{ Index 2012} & \multicolumn{5}{|c|}{ Index 2014} \\
\hline & I & II & III & IV & V & I & II & III & IV & V \\
\hline ABREVIATION & EM & EN & IN & TR & $\mathrm{CO}$ & EM & EN & IN & TR & $\mathrm{CO}$ \\
\hline Tanzania & $92 \%$ & $x$ & $55 \%$ & $2 \%$ & $28 \%$ & $81 \%$ & $X$ & $32 \%$ & $2 \%$ & $12 \%$ \\
\hline
\end{tabular}

Stages of e-government: EM = Emerging Information; EN = Enhancing information services; IN = Interaction; $\mathrm{TR}=$ Transaction services; $\mathrm{CO}=$ Connectivity

Sources: United Nations E-Government Survey 2012 and 2014

Table 3. E-government Development Stages for Tanzania.

\begin{tabular}{c|c|c|c|c|c|c|c|c}
\hline \multirow{2}{*}{ Countries } & \multicolumn{4}{|c|}{2012 Index in } & \multicolumn{4}{c}{2014 Index in } \\
\cline { 2 - 10 } & $\begin{array}{c}\text { Web } \\
\text { Measur } \\
\text { ement }\end{array}$ & $\begin{array}{c}\text { Telecomm. } \\
\text { Infra } \\
\text { Structure }\end{array}$ & $\begin{array}{c}\text { E- } \\
\text { Particip } \\
\text { ation }\end{array}$ & $\begin{array}{c}\text { E-gov } \\
\text { dev. }\end{array}$ & $\begin{array}{c}\text { Web } \\
\text { Measur } \\
\text { ement }\end{array}$ & $\begin{array}{c}\text { Telecomm. } \\
\text { Infra } \\
\text { structure }\end{array}$ & $\begin{array}{c}\text { E- } \\
\text { Particip } \\
\text { ation }\end{array}$ & $\begin{array}{c}\text { E-gov } \\
\text { dev. }\end{array}$ \\
\hline ABBREVIATION & WB & TI & EP & ED & WB & TI & EP & ED \\
\hline Tanzania & 0.3529 & 0.0839 & 0.0789 & 0.3311 & 0.2992 & 0.0808 & 0.3922 & 0.2764 \\
\hline $\ln (\%)$ & $35 \%$ & $8 \%$ & $8 \%$ & $33 \%$ & $29 \%$ & $8 \%$ & $39 \%$ & $27 \%$ \\
\hline
\end{tabular}

Source: Data taken from UN E-Government Development Index, 2012 and 2014 
At the second stage of e-government, the focus is on two-way interactions surrounding various e-government elements. The United Nations e-government survey of 2012, about 92\% shows that Tanzania had achieved one-way information publishing/ cataloguing (Table 2). However, there is a drop of about $11 \%$ on cataloguing in 2014 and that might be explained in the context of a fear of online threats and weakness across technology and institutions as shown in Table 8 . However, Table 8 shows that strengths and opportunities across technology and citizens and institutions essential for the government to move on to stage two of the e-government transformation (Kumar, 2010). Yet, to harness the interaction between two sides (the sender and receiver), there should be a persistence connectivity of the internet. Internet connectivity requires a good network infrastructure, affordable internet access, and bandwidth to sustain a connection every hour of every day (Heeks, 1998; 2001; Grönlund, 2005; Machira, 2009; Karokola \& Yngstrom, 2009; Yonazi, 2010).

According to the UN E-Government Development Index 2012/14, telecommunications infrastructure played a significant role that accounted for $35 \%$ of web measurement in the year 2012 (Table 3). This explains the adoption by several government institutions in Tanzania of websites to provide information and other online resources gateways for interacting with citizens. However, such heightened ambition for them to go online has led them to delay expansion of online services to the interaction stage. They also face a number of challenges including the need for a gateway to access and control online information (Yonazi, 2010). This turns out to be the source of online threats, risks, and insecure systems leaving institutions wide open. Therefore, security and protection of public information and data appears to be a "hindrance" limiting government from going online (Hone \& Eloff, 2002; Von, 2005; Chaula, et al, 2006; Yonazi, 2010). As a consequence, this resulted in fragmentation of IT applications, duplication of IT infrastructure, and unstandardized IT equipment, devices, and other online systems (Heeks, 1998; 2001; Grönlund, 2005).

\section{E-Government Components}

\section{The Technology Factor}

The trends of e-government use in Tanzania that have been enabled by telecommunications infrastructure to share and retrieve information online are now taking shape through a holistic approach. The SWOT analysis in Table 8 shows that a number of technology infrastructure developments have recently appeared in Tanzania that make it possible for the transformation of the national e-government project. For instance, the construction of the National ICT Broadband Backbone (NICTBB) in Tanzania 
represents a great step towards bridging the technology gap in the country. The main focus for the national ICT backbone is lowering the cost and speeding up connectivity and access to enhance communications platforms in Tanzania. This infrastructure includes the construction of the East Africa Commission UHURU and UMOJA networks, the East African Marine Systems (TEAMS) project, East African Submarine Systems (EASSY); SEACOM, COMESA, and CNS/ATN (High Level Air Traffic Control) (Chatwin \& Pazi, 2013). All these form a backbone necessary for promoting telecommunication industries for speeding up the transformation of e-government across Tanzania.

Since its inception, government institutions began utilizing the NICTBB by encouraging the telecommunications industry and other related IT sectors to connect to it. However, such developments are advancing without an institutional ICT Infrastructure Master Plan (ICTIMP) in place. In the absence of an ICTIMP, the government will continue to experience challenges in its efforts to achieve e-government milestones. Table 8 shows that some some ministries, departments and agencies are still connected to private infrastructure rather than the NICTBB and spend their own funds to cover IT development and management costs, which are rather expensive. This explains why MDAs continue to procure, install, and set up basic IT infrastructure including LANs and WANs outside the NICTBB without guidelines or an ICTIMP and do so relying on private IT companies (Chatwin \& Pazi, 2013). For example, the local area network connected to the ICTBB is believed to be a safer environment for protecting information and data sharing across MDA's. On the contrary, internal ICT infrastructure is exposed to external communications through an internet connection and thus proliferate vulnerabilities and data threats to government information. These actions have resulted in an avalanche of technology effects from the government going online (Fountain, 2001; Heeks, 2001; Karokola \& Yngstrom, 2009; Machira, 2009). Multiple institutions also fail to support full utilization of the NICTBB through a defined strategic e-government plan aimed at integrating infrastructure and forging ahead with merging related ICT infrastructure (see also Table 8).

In addition, this study analyzed the status of various IT efforts such as EWURA, ${ }^{1}$ TANESCO, ${ }^{2}$ TRA $,{ }^{3} \mathrm{NBS},{ }^{4} \mathrm{MOFEA},{ }^{5} \mathrm{MoHSW},{ }^{6} \mathrm{MoID},{ }^{7}$ and $\mathrm{Ardhi}^{8}$ that are reported

1. Energy and Water Utilities Regulatory Authority (EWURA) is an autonomous multi-sectoral regulatory authority established by the Energy and Water Utilities Regulatory Authority Act, Cap 414 of the laws of Tanzania that uses IT systems to estimate the price of oil, gas, etc. in the country.

2. Tanzania Electric Supplying Company Limited is the government company responsible for collecting utility bills and revenue from various customers in the country, they are also 
to have been implemented within government ministries and found that none of these platforms are fully integrated with each other to allow for full interactivity with citizens (see Table 5, Table 6, and Table 8).

It follows that the avalanche of technology induces the separation principle. The increasing utilization of the internet and web within government institutions forces separate devices that are attached to the internet in order to protect their data and information. Logically, one person is forced to have two devices (such as PCs): one device for sharing data and information via LAN; and the other device for connecting to the Internet. These approaches are an expensive exercise for government institutions and therefore lead to an avalanche of hardware within institutions (Heeks, 1998; 2001; 2002; Fountain, 2001).

However, cooperation within different sectors, along with social e-transformation structures, is now emerging as important and key drivers for achieving the full twoway interaction stage of e-government (Kumar, 2010). Table 7 and Table 8 suggest that responsible leaders of e-government institutions must ensure that citizens or customers are well informed concerning the utilization of e-government services and must creatively advise government top leaders.

\section{The Institutional Factor}

Going online refers in this study to the process of using ICT technology to transform work from paperwork to paperless. This approach poses abundant challenges to the Government of Tanzania's effort to provide quality online services (Heeks, 1999; West, 2004; Yildiz, 2007; Kumar, 2010; Yonazi, 2010). Table 7 and Table 8 show that government institutions continue to weaken and submit to adoption of e-government implementation structures that come along with aid or support from funding agencies or donor institutions. Such aid or support normally comes along with recommendations or requirements (West, 2004; Yildiz, 2007; Thandika, 2012) based on what is claimed

deploying IT systems for calculating, analyzing, linking, and estimating bills and data.

3. Tanzania Revenue Authority utilizes ICT or IT-related systems for tax collection around the world.

4. National Bureau of Statistics collects and analyzes data online or using IT technologies.

5. Ministry of Finance and Economic Affairs.

6. Ministry of Health and Social Welfare.

7. Ministry of Infrastructure Development.

8. The Ministry of Lands, Housing and Human Settlements Development deploys a land system, called MOLIS, that collects data and information around the country and analyzes it using IT-related technologies. 
to be working in developed countries and so would necessarily also work in Tanzania.

Government systems specifically for data and information sharing are complex and sensitive. For instance, government systems can easily be tampered with and compromised at the level of national security if the government adopts donor recommendations or requirements to allow connectivity for online interactions in absence of an IT master plan for monitoring data and information, (Choudrie et al, 2004). This seems to be a complicated question of how government institutions can balance optimal solutions without damaging the image of global and internal cooperation with the e-government transformation. Institutional leaders in the national e-government project can innovatively embrace the e-government transformation by defining good e-government policy, strategic plan, and master plan and linking them to information privacy ${ }^{9}$ and data confidentiality ${ }^{10}$ (Choudrie et al, 2004).

Havard (2007) suggests the model of virtuous leadership, which is desperately needed for embracing challenging projects like Tanzania's national e-government project. The model of virtuous leadership seems to be necessary as government institutions still struggle to respond to changes caused by technology. The model contains ten points and among them are that a virtuous leader should be virtuous, magnanimous and humble, prudent, have a leadership temperament, and have authority (Havard, 2007). This model of virtuous leadership is a far-reaching device for triggering the adoption of e-government supplemented by network actors. E-government transformation along with a social e-transformation requires global cooperation orchestrated by virtuous leadership. It should be noted that e-government is about people and their relations with government. A lack of virtuous leaders who embrace e-government projects can highly impact the effort to achieve social e-transformation (Karokola \& Yngstrom, 2009; Machira, 2009; Dhliwayo, 2009; Merwe, 2009).

\section{Location Factor}

Heeks (2003) estimated that about $85 \%$ of e-government projects in developing countries fail due to not taking into account factors such as location and the cost of internet connectivity. These factors are important drivers in the two aspects of hosting

9. Information or data privacy in this context can be understood as an individual's information or data being highly protected and inaccessible to others. http://www5.austlii.edu.au/au/ legis/cth/num_act/pa1988108/ Retrieved 2/3/2015.

10. Confidentiality is treating information or data secretly, and not using or disclosing such information or data to others without prior knowledge of the owner of the information or data. http://www5.austlii.edu.au/au/legis/cth/num_act/pa1988108/ Retrieved 2/3/2015. 
and infrastructure rollout. The Tanzanian government's ability to handle information and data infrastructure seems to lag behind the development strategy due to size and location. Tanzania has an area of about 945,203 $\mathrm{km}^{2}$ (Wikipedia, ${ }^{11}$ 2015), which implies that it is a rather big country which to roll out ICT infrastructure and ensure accessibility, connectivity, and information and data protection simultaneously in a short time given its budget. Unplanned cities, towns, and villages have contributed to the difficulties of constructing IT infrastructure. An absence of local cluster planning and designs to support IT infrastructure is another hindrance in achieving accessible IT services. This has made it difficult to ascertain the opportunities of establishing IT infrastructure in Tanzania.

In contrast, online databases and information are not hosted internally but, rather, are hosted abroad due to poor planning and coordination. This has created fear and mistrust in embracing the e-government project. However, Tanzania can embrace the use of mobile e-technology infrastructure for e-government access. Such infrastructure should be associated with governing affordable internet connectivity, managing cheap and sufficient internet bandwidth, and encouraging Wi-Fi free zone infrastructure (clustering/location).

\section{Social E-Transformation and E-Society}

Castells (2010) explored the rapid growth of technology and social involvement in the underlying framework of informationalism. He described social transformation as a fundamental notion that changes according to the speed and response to technology and transformation (Castells, 2010). The nature of technological growth as defined by Castells is essentially the determining factor in social transformation and development while increasing knowledge as far as interaction (involvement) is concerned (Castells, 2010). The rise of virtual society networks in Tanzania (network society as coined by Castells) is growing like a binary tree that connects nodes of social groups and creates interrelationships between businesses across borders. Therefore, network society is gaining speed in a technological era as a tool not only for increasing income but also for involvement in infomationalism.

Castells' argument is also based on technological responsiveness influencing innovation and social network knowledge. Even though the great contribution of the concept of informationalism is shown through a positive change in social networks along with social involvement in technology, this argument attracts more attention at the organizational level when it comes to rearranging structures and organizational forms.

11. http:// en.wikipedia.org/wiki/Tanzania Retrieved March 24, 2015. 
However, it falls short of addressing the relationship underlying institutional leadership responsiveness that can impact social networks in the process of achieving successful e-government. From Castells' perspective, social e-transformation might be a significant predictor of institutional innovation in response to the fusion of binary technology (Akman, 2008; Castells, 2010). In doing so, government institutions and social etransformation are inseparable "institutions" intervening from adoption to utilization of state of the art e-government (Akman, 2008; Castells, 2010; Hanna, 2009b).

\section{E-Governance}

Initiatives aimed towards e-government transformation depend on the three factors for institutions to flourish: transparency, accountability, and reliability (Heeks, 1998, 2001; Fountain, 2001; Evans and Yen, 2005; Coleman, 2006). However, the e-government transformation in several institutions depends on resources from donors, in terms of financial assistance, support from IT experts, IT infrastructure, IT applications, and e-government applications. In summary, it follows that institutional dependence on technology, resources, and IT expertise correlate with the inability to transform egovernment while moving to practice e-governance (virtual governance). This explains that, in the presence of donor-funded projects, financial assistance or other external support tends to form the root of corruption rather a tool to increase efficiency, productivity, transparency, and accountability (Heeks, 1998, 2001; Fountain, 2001; Evans and Yen, 2005; Coleman, 2006). These consequences have locked institutions into a dilemma and therefore have become reluctant for online transparency and accountability (e-governance) within their internal institutional structure.

\section{Virtuous Leadership}

Interest from politics and administration in embracing e-government in Tanzania is seen in a mixed approach starting from institutions going to the political level. This approach has worked, not to support the effective realization of the project, but to orchestrate the adoption and dependency on donors. Across Vertical and Hierarchical level of authority the analysis from SWOT, shows that this mixed approach of interest in embracing the e-government via donor dependency has resulted to several institutions leaders losing interest and desire to advance national e-government projects. Institutional leadership buttresses the effort of developing e-government due to the absence of governance (Heeks, 2002; Merwe; 2009). This study argues that virtuous leadership should be installed to orchestrate the transformation to e-government within institutions and to help rearrange their structures and systems. A large number of institutions 
are facing similar challenges and therefore societies should be involved in measuring the qualities of leadership as a key driver for enabling e-government in Tanzania (Heeks, 2002; Havard, 2007).

\section{Opportunities for E-Government in Tanzania}

E-government can provide a bunch of opportunities to become a universal resource for all citizens. It can be a policing tool for fighting against criminals both online and offline while reducing operating costs (Yonazi, 2010). E-government can be an ethical tool for administering and eliminating excess bureaucracy, fighting corruption, and increasing productivity (Avgerou, 2003; Bhatnagar, 2004; Yonazi, 2010; Adeyemo, 2011).

E-government can also be used as a visualization tool in educational, health, social, economic, and government institutions. More importantly, e-government can be used as an indexing tool for analyzing and projecting future population, budgeting, and planning for the people of Tanzania in all sectors. It can also be used as a piloting village for connecting and bringing people together while providing equitable goods and services. In additional, e-government in Tanzania can become an intelligence tool for the national security agency, for example signaling, monitoring, analyzing, and safeguarding online local data and information for the people via Tanzanian national security institutions. All this makes e-government a development for social transformation as well as for prosperity in Tanzania.

\section{Technology Enactment Theory (TET)}

New technologies are essentially meant to rearrange internal processes in government systems to respond to the ever-growing pressure to provide quality and equitable services to citizens, society, and across international borders. Using TET, developed by Fountain (2001), helps the current study identify three cardinal factors: institutional, technological, and citizen factors. All of these factors are explained above with reference to the analysis in Table 8 . In summary, institutions rearranged by technology are what Fountain calls the virtual state and use this new technology. In the case of Tanzania, these information age factors lag behind in the e-government developmental stage, along with institutional efforts to confront changes caused by these technologies (Yonazi, 2010). Institutions have often continued to use the stovepipe approach of taking things for granted, especially concerning fundamental issues like the national e-government project (Heeks, 1998; 2003a). Their intention is to avoid either disrupting the status quo or fear of causing the institutional changes that would attract more attention. 
This study argues that technology is a necessity and therefore should be guided by human and social factors. Leaving them out means arbitrary and unplanned development. As technology continues to grow faster in the form of a binary technology, its effects are highly associated with fear on the part of government institutions going online (Fountains, 2001; Norris et.al, 2005). However, an important argument by Fountain (2001) based on TET is a focus on the consequences of technology and not on how they originate. She pointed out that technology has brought win-win situations for both actors and customers. Efforts in many institutions are focused on guiding technology to minimize the consequences while neglecting the human factor (the customers of e-government). It follows that institutions that are responsible for governing the implementation of e-government projects take the form of a stovepipe approach in implementing e-government projects that has led to illusion of innovation within responsible institutions (Fountain, 2001). A different perspective is that the technology misfortune happens when institutions fail to assist and restructure institutions in the process of technology reconfiguration for realizing e-government.

\section{RESEARCH METHOD AND FRAMEWORK}

\section{Methodological Overview}

This study uses both quantitative and qualitative criteria as comprehensive research strategies to analyze the status, challenges, and opportunities for e-government transformation in Tanzania (Cornford \& Smithson, 1997; Yin, 2008). In the qualitative part, the study explores key challenges and opportunities using technology enactment theory (TET) and SWOT analysis of institutions, technology, and citizens. For the quantitative approach the key factors predicted to offset any limitations and improve the strength of the research findings are determined. Non-probability sampling was used to select the target population to achieve this. The target population consists of government, the private sector, educational institutions, social forums, and entrepreneurs across Tanzania (see Appendix 2). Survey respondents included individual experienced IT experts, toplevel directors and managers, public officials and academicians. The list here represents the sampling frame. The study employed a combination of judgment and quota sampling methods in order to maximize the response rate. Judgment sampling is appropriate when the researcher has knowledge of the population to be examined. However, the use of quota sampling was only to validate representation criteria within groups of interest undertaken to study. This ensured appropriate representation of various groups in the study (see Appendix 3). An online questionnaire was sent to all 104 participants 
Table 4. Analysis of the Target Population

\begin{tabular}{l|c|c|c|c|c}
\hline \multicolumn{1}{c|}{ Criteria Group } & GI & MO & LN & Al & $\begin{array}{c}\text { Response } \\
\text { Rate }\end{array}$ \\
\hline Target Population & $\begin{array}{c}\text { Government } \\
\text { Institutions }\end{array}$ & $\begin{array}{c}\text { Mobile } \\
\text { Phone } \\
\text { Operators }\end{array}$ & $\begin{array}{c}\text { Local IT } \\
\text { Industry and } \\
\text { Social } \\
\text { Networks }\end{array}$ & $\begin{array}{c}\text { Academic } \\
\text { Institutions }\end{array}$ & 26 \\
\hline Sample size & 33 & 17 & 28 & 26 & $100 \%$ \\
\hline Questionnaire size & 33 & 17 & 28 & 26 & $100 \%$ \\
\hline Sample in \% & $33 \%$ & $17 \%$ & $28 \%$ & $26 \%$ & $100 \%$ \\
\hline
\end{tabular}

Note: $\mathrm{Gl}=$ Government Institutions; $\mathrm{MO}$ = Mobile Phone Operators; LN = Local IT Industries and Social Networks; $\mathrm{Al}=$ Academic Institutions.

structured on the sampling frame (Table 4).

In addition, this study employs various sources of data, including semi-structured interviews, direct observation, participant observer, documentation, and library or archival records, which all have pros and cons (Pett et al., 2003). Data collection was administered using secondary sources from the literature review as provided in the theoretical framework and the background of the study. Some other important resources included the Central Library, Korean Ministries and information resources in Korea. The central library and other libraries at the Seoul National University, Korea was consulted.

\section{Survey Respondents}

The response rate was $100 \%$ among the 104 participants who make up valid group that responded to the study. The sample shows that about $(65 \%)$ were female respondents who predominated over male respondents $(35 \%)$. The average of the respondent age was in the 31-40 age group. In terms of education, approximately $41 \%$ had a Master's degree, while $36 \%$ had a Bachelor's degree. Only $11 \%$ of respondents were reported to possess a Ph.D. There were 40 directors of institutions (38\%) and 12 tutorial assistants (10\%) who responded to the study. Thirty-five percent of the respondents come from government institutions mandated to oversee the implementation of egovernment in the country. Only $16 \%$ are come from private institutions operating businesses on technology platforms, $17 \%$ come from social forums dealing entirely with technology and are the catalyst for broadening usage of technologies such as blogs, facebook, Google, and chatting. Meanwhile, $21 \%$ are from educational institutions geared towards training and implementing e-government in their sector such as by 
using e-government for education, teaching and learning, and grading as well as for communicating. A further $9 \%$ of respondents are private entrepreneurs connected to egovernment business on various platforms, for instance, the development of software and technological applications, and servicing IT equipment (See Appendix 1).

The questionnaire was divided into nine parts: 1) IT infrastructure for e-government development; 2) Information privacy; 3) Data security; 4) Information security for citizens; 5) Protection of citizen information; 6) Access to e-government; 7) Transparency of e-government policy; 8) Accountability of e-government development; and 9) Capacity for e-government development. This was an easy method for motivating the respondents to indicate their level of certification. A five-point Likert scale was used anchored on 5 for strongly agree and 1 for strongly disagree. This method helped the respondents orient themselves to the questions that they are familiar with and make it easy for them just to select and tick the appropriate box. Furthermore, factor analysis was employed, along with descriptive statistics.

\section{Research Framework}

The research framework in Figure 1 shows how this study organizes and uses methodological tools and the key elements of e-government. The methodology includes expert surveys and SWOT analysis. The study explores three key dimensions of the current status of e-government in Tanzania: e-government components (e.g., technology,

Figure 1. Research Framework

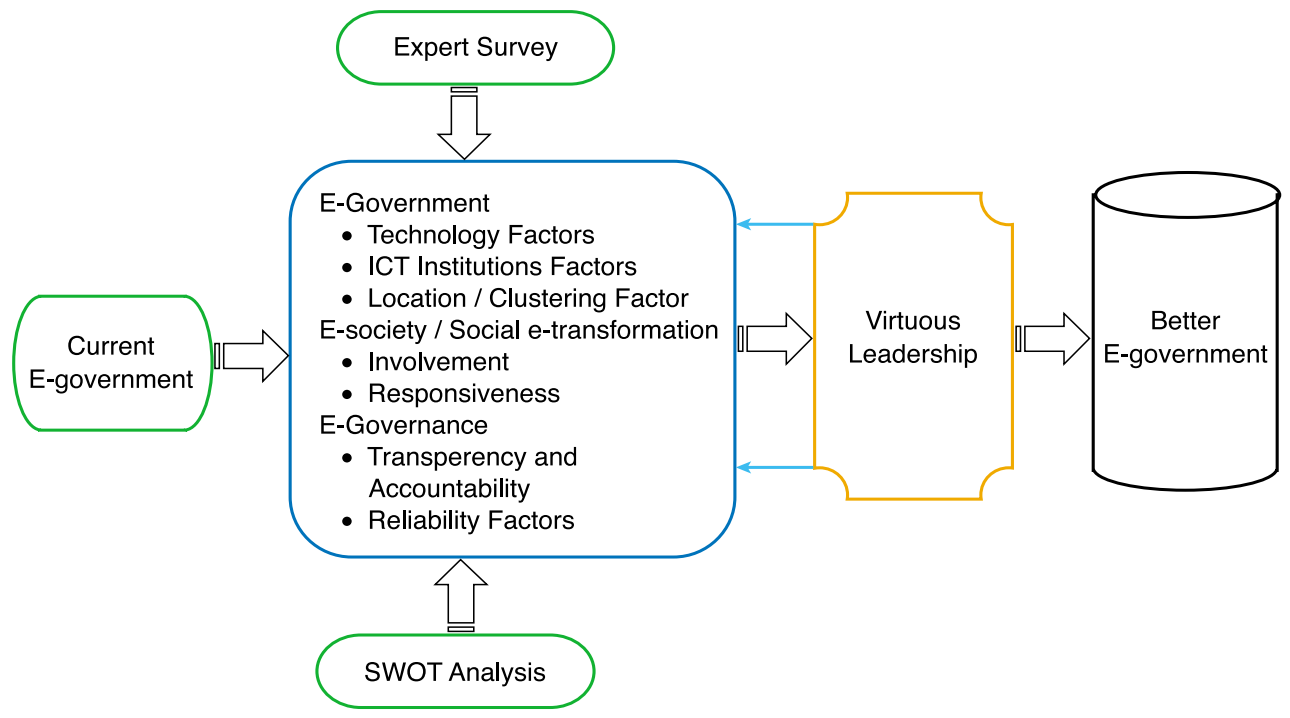


ICT institutions, and location and clustering factors), e-society and social e-transformation (e.g., involvement and responsiveness), and e-governance (transparency, accountability, and reliability). The study emphasizes virtuous leadership for promoting these components for better e-government.

\section{EMPIRCAL FINDINGS}

\section{Key Results of the Expert Survey}

\section{E-Government Development Technology}

The technology factors for analyzing e-government development based on IT Infrastructure and internet connectivity for e-government, information privacy and data security are shown in Table 5 . The 54 items measured using a five-point Likert scale were analyzed based on factor analysis using SPSS 21. The descriptive analysis includes the standard deviations and the means of the constructs. The results presented here show that the average scores for technology, citizens, and institutional variables for e-government ranges from the mean values $(\mathrm{M})$ of 1.12 to 4.92 and standard deviations (SD) of 0.27 to 0.90 .

The highest score in IT infrastructure for e-government development shows that IT infrastructure is underutilized given the mushrooming of the telecommunications industry $(\mathrm{M}=4.92 \mathrm{SD}=0.27)$ while the lowest IT infrastructure score implies that absence of IT infrastructure policy for attracting investors and multiplying utilization channels ( $\mathrm{M}=1.36$ and $\mathrm{SD}=0.48)$. However, it can be explained by the absence of IT infrastructure protection $(\mathrm{M}=1.96$ and $\mathrm{SD}=0.90)$ as well as weak IT infrastructure management by government and the private sector $(\mathrm{M}=1.92$ and $\mathrm{SD}=0.27)$. As a result, this study concludes that the current situation in Tanzania continues to experience the internet mobile access to be rather expensive to accommodate citizens.

Similar to the information privacy effect, which shows that information and data are widely shared through mobile phones, the internet, email, and websites explaining the significance of the lack of an e-government master plan $(\mathrm{M}=4.92$ and $\mathrm{SD}=0.27)$, this shows that technological innovation is hampered and government continues to suffer regarding the use, disclosure, and protection of information sharing in the absence of virtuous leadership $(\mathrm{M}=1.69$ and $\mathrm{SD}=0.50)$. The analysis of data security shows high scores for Tanzania not having a database infrastructure $(\mathrm{M}=4.86$ and SD $=0.35$ ) while the lowest score is for government institutions lacking leadership on serious issues such as data privacy policy, and strong regulations and laws governing 
Table 5. Technology Variables of E-Government, Information Privacy, and Data Security

\begin{tabular}{|c|c|c|}
\hline IT Infrastructure for e-government development & Mean & S.D \\
\hline TQ11 (The IT infrastructure is partially utilized) & 4.58 & 0.69 \\
\hline $\begin{array}{l}\text { TQ12 (The IT infrastructure is well protected against hackers, malicious } \\
\text { programs, etc.) }\end{array}$ & 1.96 & 0.90 \\
\hline TQ13 (IT infrastructure is well managed by government and the private sector) & 1.92 & 0.27 \\
\hline TQ14 (There is a clear IT infrastructure policy in place) & 1.36 & 0.48 \\
\hline $\begin{array}{l}\text { TQ15 (The advancement of IT technology affects the sustainability of the } \\
\text { IT infrastructure) }\end{array}$ & 4.61 & 0.64 \\
\hline TQ16 (There is no IT infrastructure master plan for e-government development) & 4.92 & 0.27 \\
\hline Information privacy & Mean & S.D \\
\hline $\begin{array}{l}\text { TQ21 (Information is widely shared through mobile phones, the internet, email, } \\
\text { and websites) }\end{array}$ & 4.92 & 0.27 \\
\hline $\begin{array}{l}\text { TQ22 (Private companies manage email, blogs, and websites in the civic and } \\
\text { government sectors) }\end{array}$ & 4.87 & 0.34 \\
\hline TQ23 (There is a clear information privacy policy in place) & 1.75 & 0.48 \\
\hline TQ24 (There is strong regulation and law governing information sharing) & 1.75 & 0.48 \\
\hline $\begin{array}{l}\text { TQ25 (There is clear agreement between individuals, companies, and government } \\
\text { regarding the use, disclosure, and protection of information sharing) }\end{array}$ & 1.69 & 0.50 \\
\hline TQ26 (There is no information privacy master plan setup by government) & 4.70 & 0.46 \\
\hline Data security & Mean & S.D \\
\hline TQ31 (There is no database infrastructure in the country) & 4.86 & 0.35 \\
\hline TQ32 (Private companies manage citizen and government data') & 4.86 & 0.35 \\
\hline TQ33 (There is a clear data privacy policy in place) & 1.12 & 0.32 \\
\hline TQ34 (There is strong regulation and law governing data sharing) & 1.12 & 0.32 \\
\hline $\begin{array}{l}\text { TQ35 (There is clear agreement between individuals, companies, and government } \\
\text { regarding the use, disclosure, and protection of data sharing) }\end{array}$ & 1.20 & 0.40 \\
\hline TQ36 (There is no data security master plan set up by the government) & 4.92 & 0.27 \\
\hline
\end{tabular}

Note: $\mathrm{N}=104$. All items are measured by a Likert scale from 1 (strongly disagree) to 5 (strongly agree).

data sharing $(\mathrm{M}=1.12$ and $\mathrm{SD}=0.32)$. On average, IT infrastructure for e-government and information privacy are deemed to be the most crucial for e-government development $(\mathrm{M}=4.92, \mathrm{M}=4.70)$ while the most urgent critical issue is database infrastructure and security protection $(M=4.92)$ 


\section{Social e-Transformation}

The perceived social e-transformation in the process of e-government is believed to play a significant role in information security and access is reflected in the SWOT analysis in Table 8 . The respondents indicated that social e-transformation should be framed into bringing change perpendicular with the rapid change of technology growth. The social e-transformation is directly associated with stovepiping, along with imposing penalties for any violation or misuse of citizen or government information $(\mathrm{M}=4.37$ and $\mathrm{SD}=0.86)$ whereas institutional responsibility and accountability for online transactions were loaded with low scores, which implies that there is a significant leadership effect $(\mathrm{M}=1.06$ and $\mathrm{SD}=0.23)$. This result supports the explanation that government capability for handling database infrastructure, managing, encrypting databases and information is always compromised $(\mathrm{M}=1.10$ and $\mathrm{SD}=0.30)$. Therefore, on average, social e-transformation is perceived as a critical success factor for egovernment associated with citizen and government database and information security and protection $(\mathrm{M}=1.91, \mathrm{M}=1.26)$. Combined with the SWOT analysis, this shows that the most important factor is having virtuous leadership in place to embrace the entire e-government project from database and information to citizen interaction or side-by-side with social e-transformation $(\mathrm{M}=1.46, \mathrm{M}=1.61, \mathrm{M}=2.15)$.

Table 6. Social e-Transformation Variables of Information Security, Information Protection, and Access

\begin{tabular}{l|c|c}
\hline \multicolumn{1}{c|}{ Information security for citizens } & Mean & SD \\
\hline $\begin{array}{c}\text { CQ11 (Government imposes strong penalties for any violation or misuse of } \\
\text { citizen and government information) }\end{array}$ & 4.37 & 0.86 \\
\hline $\begin{array}{c}\text { CQ12 (E-government institutions are responsible for any loose or transacted } \\
\text { citizen information or data) }\end{array}$ & 1.06 & 0.23 \\
\hline $\begin{array}{c}\mathrm{CQ13} \text { (E-government institutions provides signals or alerts to citizens in case } \\
\text { of any information shared online) }\end{array}$ & 1.91 & 0.50 \\
\hline $\begin{array}{c}\mathrm{CQ14} \text { (Government's ability to handle the citizen database infrastructure is } \\
\text { assured for easy online sharing) }\end{array}$ & 1.10 & 0.30 \\
\hline $\begin{array}{c}\mathrm{CQ15} \text { (E-government institutions coordinate agreement between citizens and } \\
\text { third partes for sharing and accessing information or data) }\end{array}$ & 1.46 & 0.50 \\
\hline $\begin{array}{c}\mathrm{CQ16} \text { (Telephone companies and internet hosts companies fulfill the } \\
\text { agreement between citizens (users) and companies in the presence of } \\
\text { government prosecutors or lawyers) }\end{array}$ & 1.16 & 0.37 \\
\hline
\end{tabular}




\begin{tabular}{|c|c|c|}
\hline Protection of citizen information & Mean & SD \\
\hline CQ31 (Citizen information and databases are strictly protected by government) & 1.16 & 0.37 \\
\hline $\begin{array}{l}\text { CQ32 (Individual databases cannot be shared unilaterally without prior } \\
\text { permission from the owner) }\end{array}$ & 1.42 & 0.50 \\
\hline $\begin{array}{l}\text { CQ33 (Government coordinates special agreement for using citizen information } \\
\text { privately only for purpose of national development) }\end{array}$ & 2.15 & 1.15 \\
\hline $\begin{array}{l}\text { CQ34 (IT equipment used to access government or citizen data and information } \\
\text { are highly encrypted and recorded for future evidence) }\end{array}$ & 1.10 & 0.30 \\
\hline $\begin{array}{l}\text { CQ35 (Government institutions impose restrictions for using IT devices to share, } \\
\text { retrieve, and store data or information without standardized permit) }\end{array}$ & 1.26 & 0.44 \\
\hline $\begin{array}{l}\text { CQ36 (Government imposes a strong policy for online communications on } \\
\text { the web, internet, blogs, facebook, etc. to access and share information } \\
\text { or data) }\end{array}$ & 1.61 & 1.06 \\
\hline Access to e-government & Mean & SD \\
\hline CQ41 (Online government data retrieval takes a short time to download) & 2.71 & 1.12 \\
\hline $\begin{array}{l}\text { CQ42 (Government institutions control websites that are very simple to run on } \\
\text { any platform (mobile phones, laptops, PDAs etc.) }\end{array}$ & 1.73 & 0.45 \\
\hline $\begin{array}{l}\text { CQ43 (Government websites limit authorization to access online citizen } \\
\text { information without permission) }\end{array}$ & 3.10 & 0.86 \\
\hline $\begin{array}{l}\text { CQ44 (Government websites provide citizens basic and updated information } \\
\text { every day) }\end{array}$ & 1.88 & 0.56 \\
\hline CQ45 (It takes seconds to upload information to government websites) & 1.90 & 0.30 \\
\hline $\begin{array}{l}\text { CQ46 (Government websites provide ease of use (language, searching } \\
\text { buttons, information transaction, data retrieval, etc.)) }\end{array}$ & 2.24 & 0.98 \\
\hline
\end{tabular}

\section{Institutional Capacity and E-Governance Factor}

Aid and donor dependency has affected innovation and capability in many institutions leading them to become docile to donors. The intention of adopting e-government framework and strategies are affected by institutional innovation, a low level of IT knowledge by IT experts, and other factors as reported in Table 7. The highest government institution score is linked to corruption as a consequence of creating conflicts of interest and lack of accountability $(\mathrm{M}=4.98$ and $\mathrm{SD}=0.14)$. This is supported by the explanation that fear of transparency, accountability, and responsibility leads egovernment efforts into a coma $(\mathrm{M}=1.08$ and $\mathrm{SD}=0.27)$. The SWOT analysis results combined with the factor analysis may add value to the explanation that e-government institutions require the strong will of politicians and other government officials, a social e-transformation structure in place, and the dynamic capability of e-government 
Table 7. Transparency, Accountability, and Capacity Variables for E-Government Development

\begin{tabular}{|c|c|c|}
\hline Transparency of e-government policy & Mean & S.D \\
\hline $\begin{array}{l}\text { IQ11 (Investment in e-government development should be shared with all } \\
\text { citizens, companies, and government organizations) }\end{array}$ & 1.28 & 0.45 \\
\hline $\begin{array}{l}\text { IQ12 (E-government development should be supported by political leaders, } \\
\text { politicians, and government officials) }\end{array}$ & 1.46 & 0.50 \\
\hline $\begin{array}{l}\text { IQ13 (Directors, managers, employees, and citizens are not aware of the } \\
\text { e-government development budget) }\end{array}$ & 1.41 & 0.49 \\
\hline IQ14 (Citizens are well informed about each stage of IT development project) & 1.35 & 0.48 \\
\hline $\begin{array}{l}\text { IQ15 (Directors, managers, and employees avoid sharing information publically } \\
\text { in order to protect their power and current interests) }\end{array}$ & 4.78 & 0.52 \\
\hline $\begin{array}{l}\text { IQ16 (Leaders of e-government institutions have no master plan to influence } \\
\text { the development of e-government policies, strategies, and laws) }\end{array}$ & 4.84 & 0.40 \\
\hline Accountability for e-government development & Mean & S.D \\
\hline $\begin{array}{l}\text { IQ21 (E-government leaders report to citizens about e-government } \\
\text { development in a timely manner) }\end{array}$ & 1.08 & 0.27 \\
\hline $\begin{array}{l}\text { IQ22 (E-government leaders take responsibility for any fraud stemming from } \\
\text { e-government development) }\end{array}$ & 2.26 & 1.19 \\
\hline $\begin{array}{l}\text { IQ23 (Directors, managers, and e-government leaders are held accountable } \\
\text { for their actions) }\end{array}$ & 2.20 & 1.23 \\
\hline $\begin{array}{l}\text { IQ24 (Leaders avoid taking responsibility due to conflict of interest in } \\
\text { e-government project development) }\end{array}$ & 4.98 & 0.14 \\
\hline $\begin{array}{l}\text { IQ25 (Workers and government employees lack the political orientation to } \\
\text { embrace any IT project development) }\end{array}$ & 4.82 & 0.48 \\
\hline $\begin{array}{l}\text { IQ26 (There is no master plan for e-government institutions to coordinate the } \\
\text { development of e-government) }\end{array}$ & 4.82 & 0.39 \\
\hline Capacity of e-government development & Mean & S.D \\
\hline $\begin{array}{l}\text { DV1 (Directors, managers, and e-government leaders are very strong in their } \\
\text { implementation actions) }\end{array}$ & 3.84 & 0.83 \\
\hline $\begin{array}{l}\text { DV2 (Leaders of e-government institutions are very smart in making decisions } \\
\text { along with the speed of IT development) }\end{array}$ & 4.82 & 0.40 \\
\hline $\begin{array}{l}\text { DV3 (Due to innovation e-government institutions are able to respond to online } \\
\text { data or information sharing) }\end{array}$ & 1.31 & 0.46 \\
\hline $\begin{array}{l}\text { DV4 (The binary technology tree transforms culture and society cascading } \\
\text { from e-government leaders to citizens) }\end{array}$ & 4.61 & 0.60 \\
\hline $\begin{array}{l}\text { DV5 (Due to e-government workers, decisions based in e-government } \\
\text { development are normally corruption free) }\end{array}$ & 4.14 & 0.49 \\
\hline $\begin{array}{l}\text { DV6 (The inversion of new technologies within government makes it effective } \\
\text { and speedy to decide, initiate, and forge ahead with the development } \\
\text { of e-government) }\end{array}$ & 4.41 & 0.78 \\
\hline
\end{tabular}


project leaders $(\mathrm{M}=1.46, \mathrm{M}=1.35, \mathrm{M}=1.41)$. Overall, there is a strong need for virtuous institutional leaders who would devote significant effort to implementing an e-government master plan to influence development of other instruments such as egovernment policies, strategies, and laws $(M=4.84, M=4.82)$. In addition, it is an urgent issue in Tanzania that leaders of e-government institutions are required to have strong capability for innovation and making smart decisions $(\mathrm{M}=3.84, \mathrm{M}=4.82)$. Leaders of government institutions should realize that e-government transformation goes hand in hand with the social e-transformation $(\mathrm{M}=4.61)$ and adhere to rapid change $(\mathrm{M}=4.41)$.

\section{Descriptive Findings from the SWOT Analysis}

The current study employs technology enactment theory (TET) as a research framework to understand and analyze the status, challenges, and opportunities facing e-government transformation in Tanzania. TET (Fountain, 2001) suggests institutional, technological, and citizen factors as paramount. All these factors are explained through the SWOT analysis depicted in the analysis in Table 8.

The SWOT analysis was applied to ascertain the current strengths, weaknesses, opportunities, and threats along with qualitative methods for e-government transformation. The prime objective of employing this analysis is based on determining the status of e-government in Tanzania focusing on technology, institutions, and citizens as factors identified in the technology enactment theory (Fountain, 2001). The approach used here is based on the theoretical framework adopted from Fountain (2001) in this study. This approach is coupled with an empirical analysis of e-government transformation (Ritson, 2011). In so doing, current status, challenges, and opportunities were analyzed to validate the current methods.

Ritson (2011: 41) argued that SWOT analysis is the most powerful tool for analyzing and matching factors for different situations to make suggestions for future planning. The study adopted this concept by matching the findings from the SWOT analysis in Table 8 and converting them into meaningful results (Ritson, 2011). For instance, the study matches the strengths and opportunities to forecast the competitive factors and at the same time uses a conversation analysis to offset the weaknesses or threats as suggested by Ritson (2011). 
Table 8. Summary of SWOT vs. the Technology, Institution, and Citizen (TIC) Analysis

\begin{tabular}{|c|c|c|c|c|}
\hline SWOT / TIC & $\begin{array}{c}\text { STRENGTHS } \\
\text { (S) }\end{array}$ & $\begin{array}{l}\text { WEAKNESSES } \\
\text { (W) }\end{array}$ & $\begin{array}{l}\text { OPPORTUNITIES } \\
(\mathrm{O})\end{array}$ & $\begin{array}{l}\text { THREATS } \\
(\mathrm{T})\end{array}$ \\
\hline $\begin{array}{l}\text { TECHNOLOGY } \\
\text { (T) }\end{array}$ & $\begin{array}{l}\text { - Connectivity } \\
\text { infrastructure available } \\
\text { - LAN in each MDAS } \\
\text { infrastructure available } \\
\text { - Emerging national } \\
\text { fiber optic infrastructure, } \\
\text { SEACOM, EASSY, } \\
\text { Mkongo, UHURU and } \\
\text { UMOJA networks, etc. } \\
\text { - Web connectivity } \\
\text { infrastructure } \\
\text { - Government network } \\
\text { connecting } 72 \\
\text { organizations, including } \\
\text { all Ministries and } \\
\text { some Government } \\
\text { Departments and } \\
\text { Agencies amounting }\end{array}$ & $\begin{array}{l}\text { - Cost of e-government } \\
\text { development of is } \\
\text { relatively high } \\
\text { - Lack of standardization } \\
\text { of technology, } \\
\text { applications } \\
\text { - Delays in implementing } \\
\text { e-government projects } \\
\text { due to bureaucratic } \\
\text { procedures } \\
\text { - Absence of } \\
\text { e-government master } \\
\text { plan for ICT } \\
\text { infrastructure, for IT } \\
\text { enterprise architecture, } \\
\text { for policies and strategy } \\
\text { (ICT Policy, Security } \\
\text { Policy, Cybercrime } \\
\text { Policy, IT infrastructure } \\
\text { Policy, etc.) } \\
\text { - High cost of internet } \\
\text { access and } \\
\text { infrastructure } \\
\text { development }\end{array}$ & $\begin{array}{l}\text { - Benchmarking of high } \\
\text { technology opportunities } \\
\text { - Technological best } \\
\text { practice adaptability } \\
\text { and innovation } \\
\text { - Human development } \\
\text { capacity for IT/ICT } \\
\text { programs } \\
\text { - Submarine, national } \\
\text { fiber, and other ongoing } \\
\text { ICT/IT infrastructure } \\
\text { - E-government as a } \\
\text { tool for ethical, police, } \\
\text { indexing, piloting } \\
\text { village, intelligence } \\
\text { and visualization tools } \\
\text { within government } \\
\text { institutions and the } \\
\text { private sector } \\
\text { - Involveing PPPs, } \\
\text { NGOs and other public } \\
\text { network players in } \\
\text { implementing } \\
\text { e-government }\end{array}$ & $\begin{array}{l}\text { - Dependency on } \\
\text { donor-funded } \\
\text { IT/ICT projects } \\
\text { - Absence of data } \\
\text { warehouses, recovery, } \\
\text { and security plan } \\
\text { - Systems } \\
\text { incompatibility for } \\
\text { integrated platforms } \\
\text { - Security infrastructure } \\
\text { a stumbling block for } \\
\text { e-government } \\
\text { - Weak policies related } \\
\text { to IT/ICT, IT enterprise } \\
\text { architecture } \\
\text { - E-government causes } \\
\text { problems for } \\
\text { development } \\
\text { - Illusion of innovation } \\
\text { - Avalanche of } \\
\text { technology } \\
\text { - Misfortune of } \\
\text { technology }\end{array}$ \\
\hline $\begin{array}{l}\text { INSTITUTIONS } \\
\text { (I) }\end{array}$ & $\begin{array}{l}\text { - ICT policy and } \\
\text { e-government strategy } \\
\text { ready for adoption } \\
\text { - Will to embrace Private, } \\
\text { public Partnership } \\
\text { - Political stability and } \\
\text { embrace of new forms } \\
\text { of technology } \\
\text { - MDAs and government } \\
\text { institutions embrace } \\
\text { the e-government } \\
\text { transformation } \\
\text { - E-government as a new } \\
\text { institutional routine } \\
\text { - E-government } \\
\text { providing mindful } \\
\text { stability to institutions }\end{array}$ & $\begin{array}{l}\text { - Fear of transparency } \\
\text { or accountability / } \\
\text { conflicts of interest } \\
\text { - Lack of innovation by } \\
\text { IT/ICT experts } \\
\text { - Weak collaboration of } \\
\text { PPP, NGO's, citizens } \\
\text { in IT/ICT development } \\
\text { projects } \\
\text { - Weak institutional } \\
\text { responsibility in } \\
\text { technological innovation } \\
\text { and informatization } \\
\text { - Technological path } \\
\text { dependence } \\
\text { - Lack of institutional } \\
\text { innovation } \\
\text { - Lack of enlightened } \\
\text { leadership self-interest }\end{array}$ & $\begin{array}{l}\text { - Leadership and } \\
\text { institutional } \\
\text { arrangements } \\
\text { - Collaboration with } \\
\text { PPPs, NGOs, and } \\
\text { business networks } \\
\text { - Retaining high profile } \\
\text { professionals in ICT/IT } \\
\text { innovation } \\
\text { - In-house capacity } \\
\text { building in the area of } \\
\text { e-government }\end{array}$ & $\begin{array}{l}\text { - Rapid implementation } \\
\text { without key } \\
\text { stakeholders, NGOs, } \\
\text { or PPP collaboration } \\
\text { - Lack of adequate law } \\
\text { and regulation to } \\
\text { support e-government } \\
\text { transformation } \\
\text { - High dependency and } \\
\text { subcontracting of } \\
\text { ICT/IT services to } \\
\text { outside institutions } \\
\text { - Absence of qualified } \\
\text { and visionary leaders } \\
\text { in e-government } \\
\text { - Weak leadership and } \\
\text { IT/ICT expertise } \\
\text { innovation and } \\
\text { creativity }\end{array}$ \\
\hline
\end{tabular}




\begin{tabular}{|c|c|c|c|c|}
\hline SWOT / TIC & $\begin{array}{l}\text { STRENGTHS } \\
\text { (S) }\end{array}$ & $\begin{array}{l}\text { WEAKNESSES } \\
\text { (W) }\end{array}$ & $\begin{array}{c}\text { OPPORTUNITIES } \\
(\mathrm{O})\end{array}$ & $\begin{array}{c}\text { THREATS } \\
(\mathrm{T})\end{array}$ \\
\hline CITIZENS (C) & $\begin{array}{l}\text { - Citizens need quality } \\
\text { of service, and so } \\
\text { e-government is the } \\
\text { only way to enhance } \\
\text { quality of service } \\
\text { - Programs for } \\
\text { awareness of } \\
\text { e-government are } \\
\text { now emerging } \\
\text { - Citizens are aware of } \\
\text { and benefit from some } \\
\text { available e-government } \\
\text { services (e.g. online } \\
\text { payment to Tanzania } \\
\text { Revenue Authority } \\
\text { TRA, TANESCO, and } \\
\text { DAWASCO etc. }\end{array}$ & $\begin{array}{l}\text { - Lack of local content } \\
\text { for citizens to use } \\
\text { - Lack of knowledge in } \\
\text { deploying online } \\
\text { services } \\
\text { - Inability to change } \\
\text { mindset to trust online } \\
\text { information } \\
\text { - Lack of law/policy to } \\
\text { protect citizens in } \\
\text { utilization of online } \\
\text { services }\end{array}$ & $\begin{array}{l}\text { - Creating an } \\
\text { e-government } \\
\text { informatization } \\
\text { outreach program } \\
\text { - Embracing regional/ } \\
\text { cluster IT/ICT } \\
\text { development centers } \\
\text { - Stimulating the use of } \\
\text { ICT/IT through local } \\
\text { citizens, PPPs, and } \\
\text { NGO collaboration } \\
\text { - Social transformation } \\
\text { in terms of } \\
\text { e-government, } \\
\text { technology platforms } \\
\text { for economic } \\
\text { prosperity }\end{array}$ & $\begin{array}{l}\text { - Cyber security in } \\
\text { e-government }\end{array}$ \\
\hline
\end{tabular}

\section{Matching the SWOT Analysis}

\section{Strengths \& Opportunities}

The SWOT analysis explains that Tanzania possesses a great strength in terms of existing IT infrastructure (National ICT Broadband Backbone - NICTBB) that can facilitate the speedy transformation of the national e-government project. Institutions can take that as an opportunity for collaborating to enhance the development of an egovernment master plan, human capital development, and increase transparency and effectiveness in the utilization of the NICTBB.

When Tanzania is analyzed with reference to Kenya and Korea, Table 9 shows that the absence of an e-government master plan, e-government policy master plan, e-security master plan, and ICT infrastructure master plan made the e-government project lag behind in speed of transformation as compared to Korea., The absence of these instruments in Tanzania was the genesis of the duplication of technological applications and the mushrooming of IT and telecommunications businesses that raise the cost of internet access and infrastructure. As a result, this prompts the leading government institutions towards a propensity to technology embroidery caused by fear of making decisions in the phase of e-government. Tanzania still has an opportunity to learn from both Korea and Kenya at the same time. The focus should be to have an e-government master plan that can be a telescope to look ahead to foresee implementation through a universal approach alongside the proposed e-government framework similar to the one used in 
Table 9. Summary of the Comparison: Developed and Developing Countries

\begin{tabular}{|c|c|c|}
\hline $\begin{array}{l}\text { INDEPENDENT } \\
\text { VARIABLES }\end{array}$ & $\begin{array}{l}\text { DEVELOPED COUNTRIES } \\
\text { [KOREA] }\end{array}$ & $\begin{array}{l}\text { DEVELOPING COUNTRIES } \\
\text { [TANZANIA AND KENYA] }\end{array}$ \\
\hline TECHNOLOGY & $\begin{array}{l}\text { - Highly advanced and integrated } \\
\text { technological infrastructure } \\
\text { - Advanced security infrastructure with } \\
\text { e-government enterprise architecture } \\
\text { - Decentralized approaches in } \\
\text { implementing e-government } \\
\text { - Well-coordinated planning and } \\
\text { management in e-government } \\
\text { implementation } \\
\text { - Effective management, design, and } \\
\text { planning of local content } \\
\text { - Encourages private sector involvement } \\
\text { in IT infrastructure and applications } \\
\text { investment }\end{array}$ & $\begin{array}{l}\text { - Fragmented IT infrastructure and } \\
\text { coordination } \\
\text { - Absence of e-government enterprise } \\
\text { architecture and security infrastructure } \\
\text { - Weak design for supporting favorable } \\
\text { local content, updates, and coherent } \\
\text { structure } \\
\text { - Uncoordinated e-government projects, } \\
\text { unrealistic planning, management, and } \\
\text { implementation framework } \\
\text { - Centralized approach to e-government } \\
\text { implementation }\end{array}$ \\
\hline INSTITUTION & $\begin{array}{l}\text { - Effective e-government strategies, } \\
\text { policies and laws in place } \\
\text { - Strong leadership and political will to } \\
\text { embrace e-government transition } \\
\text { - Strong presidential interest in } \\
\text { e-government } \\
\text { - More vigorous in innovations in } \\
\text { science and technology research and } \\
\text { development } \\
\text { - Vigorous and dynamic institutional } \\
\text { innovation }\end{array}$ & $\begin{array}{l}\text { - E-government projects are driven by } \\
\text { government } \\
\text { - Path dependent on donor-funded } \\
\text { e-government projects } \\
\text { - Unrealistic design of e-government } \\
\text { structure, laws, and policies for } \\
\text { implementation } \\
\text { - Bureaucracy in decision making that } \\
\text { delays project implementation and } \\
\text { innovation } \\
\text { - Cowardly institutions in terms of } \\
\text { innovation and creativity }\end{array}$ \\
\hline CITIZEN & $\begin{array}{l}\text { - E-government projects are driven by } \\
\text { public and government } \\
\text { - Stakeholder, citizen, and government } \\
\text { participation in policy from formulation } \\
\text { to implementation stages } \\
\text { - High level of citizen awareness of the } \\
\text { use of e-government } \\
\text { - Social transformation parallel with the } \\
\text { velocity of e-government innovation } \\
\text { becoming a new routine for protection } \\
\text { and data security }\end{array}$ & $\begin{array}{l}\text { - Weak interaction and participation } \\
\text { - Technophobia from high risk of online } \\
\text { information and trust } \\
\text { - Low level of awareness of the use and } \\
\text { adoption of e-government } \\
\text { - Cowardly self-interest and increase in } \\
\text { hypocrisy in social transformation } \\
\text { against the speed of e-government } \\
\text { innovation increasing threats and risks }\end{array}$ \\
\hline
\end{tabular}

developed countries such as Korea (see Table 8 and Table 9).

Tanzania has several strengths in areas such as investors/donors/agencies that can be used to collaborate with and implement the national Tanzanian e-government project and ensure equitable services to its citizens. There are opportunities for government institutions to find virtuous leaders to play a significant role in the development of the ICT/e-government Master Plan, policies for information privacy, construction of database 
centers, backup strategic plans, and implementing strategic e-government plans. The target is discouraging high prices and encouraging affordable internet connections for attracting the use of mobile internet and e-government in areas where they cannot enjoy NICTBB due to location and distance.

Overall, location was an important driver to consider, in two aspects: hosting and infrastructure introduction. About $90 \%$ of respondents indicated that the Tanzanian government's ability to handle information and data infrastructure should be assured. Online information and databases should be hosted internally rather than abroad as is currently the case. This has created fear and mistrust of embracing e-government. Secondly, as noted above, Tanzania has a large area. Tanzania is a large country for introducing ICT infrastructure and ensuring accessibility, connectivity, and information and data protection in such a short time with the available budget. However, an opportunity is that Tanzania can embrace the use of mobile technology infrastructure for e-government access. Such infrastructure should be associated with governing affordable internet connectivity, managing sufficient internet bandwidth, and encouraging Wi-Fi free zone infrastructure. Realizing this requires social e-transformation alongside the proposed e-government framework (see Table 12).

\section{The Conversion of Weakness and Threats}

The SWOT analysis shows that the major area of weakness that Tanzania is facing is on the reluctance for many leaders of government institutions to embrace of transparency and accountability in the project of e-government transformation. On the other hand, the opportunity is for seriously installing virtuous leaders who would help enrich other leaders by changing their attitudes, values, and behavior in the direction of rearranging institutions and their structures (Fountains, 2001). Increasing transparency and accountability (Heeks, 1998; 2001) and balancing online services (Coleman, 2007) are fundamental factors for success. Not addressing them implies that institutional weaknesses will continue to intensify in the face of technology illusion and misfortune as well as experiencing an avalanche of technology. These will leads to the transformation of unreachable e-government milestones. One way to avoid this is for leaders to take charge of establishing research and development centers for e-government to avoid external forces that lead to institutional docility.

\section{Explanation of the Comparison}

Assuming all things are equal (ceteris paribus) in the context of high economic growth, political stability, and citizens, the current study suggests that the social e- 
transformation may provide a learning pattern for influencing institutional innovation techniques for sustainable development of e-government. Unlike in Kenya, government institutions are becoming more cowardly in terms of innovation and creativity, path dependent and have a weakened ability to oversee e-government in all spheres of its transformation. At the level of technology, if it is assumed that plan A fails due to budget limitations, then plan $\mathrm{B}$ is executed at the expense of rent-seeking from external development agencies or donors. The analysis shows that these institutions become more docile and driven by donors and other alien institutions whose contribution is based on their strict policy blueprints. Taking plan A into account, it is evidently that centralized project funds are available and disbursed on the basis of the medium-term national budget in the budget cycle. Similar to the empirical results and the literature review, it shows that these become the root of problems such as a delay of IT project implementation, misallocation of funds, corruption, institutional favoritism, and fragmentation of IT projects. At the citizen level, society seems to be uninformed concerning technology development and therefore continues to struggle as they learn by doing. In turn, this approach has created problems, including cowardly self-interest in social etransformation, increase of online interaction without guidelines, increase of information risks and privacy concerns, increase in pornography, abuse of technology and eventually leads to an avalanche of technology, and the illusion of technology innovation. These effects are well covered in the literature section.

More efforts are being made in the case of Korea to integrate all applications and support into a seemingly protected and secure infrastructure (Table 9). Joint initiatives from a diverse group of actors, including public and private partnerships, should network, interact and collaborate strongly to achieve expected results. Institutional, technological, and citizen factors should not be viewed in isolation but, rather, they are all intimately intertwined or interwoven. The whole process may be doomed to fail without a relevant combination all three of these factors.

\section{Exploring Key Components of the E-Government Process in Tanzania}

To validate the findings from the SWOT analysis, the factor analysis was done to explore the key statistically consistent factors related to e-government development. Five factors including ICT infrastructure (Factor 1), e-government participation and support (Factor 2), ICT policy (Factor 3), e-government leadership (Factor 4), and bureaucracy (Factor 5) were found. These factors are key elements of e-government transformation in Tanzania as captured in the SWOT analysis table 8.

ICT is associated with the variables TQ13 (IT infrastructure is well managed by government and the private sector), TQ15 (The advancement of IT technology affects 
the sustainability of IT infrastructure), TQ16 (There is no IT infrastructure master plan for e-government development), TQ21 (Information is widely shared through mobile phones, internet, email, and websites), TQ22 (Private companies manage emails, blogs, and websites in civic and government sectors), and TQ36 (There is no data security master plan set up by the government). E-government participation support is associated with institutional variables such as IQ11 (Investment in e-government development should be shared with all citizens, companies, and government), IQ12 (E-government development should be supported by political leaders, politicians, and government officials), IQ13 (Directors, managers, employees, and citizens are not aware of the e-government development budget), and IQ14 (Citizens are well informed about each stage of IT project development). The ICT policy factor is associated with

Table 10. A Preliminary Factor Analysis: Five Key Components of E-Government in Tanzania

\begin{tabular}{|c|c|c|c|c|c|c|}
\hline & Factor 1 & Factor 2 & Factor 3 & Factor 4 & Factor 5 & Cronbach's $\alpha$ \\
\hline & $\begin{array}{c}\text { ICT } \\
\text { INFRASTRU } \\
\text { CTURE }\end{array}$ & $\begin{array}{c}\text { E-GOV } \\
\\
\text { PARTICIPTION } \\
\text { SUPPORT }\end{array}$ & ICT POLICY & $\begin{array}{c}\text { E-GOV } \\
\text { LEADERSHIP }\end{array}$ & BUREAUCRACY & \\
\hline $\begin{array}{l}\text { TQ13 } \\
\text { TQ15 } \\
\text { TQ16 } \\
\text { TQ21 } \\
\text { TQ22 } \\
\text { TQ36 }\end{array}$ & $\begin{array}{l}0.9827 \\
0.6712 \\
0.9827 \\
0.9827 \\
0.7768 \\
0.9827\end{array}$ & $\begin{array}{r}-0.0003 \\
0.3911 \\
-0.0003 \\
-0.0003 \\
-0.2037 \\
-0.0003\end{array}$ & $\begin{array}{r}0.0684 \\
0.2964 \\
0.0684 \\
0.0684 \\
-0.0489 \\
0.0684\end{array}$ & $\begin{array}{r}0.0829 \\
-0.1582 \\
0.0829 \\
0.0829 \\
0.2490 \\
0.0829\end{array}$ & $\begin{array}{r}-0.0694 \\
0.1924 \\
-0.0694 \\
-0.0694 \\
-0.0634 \\
-0.0694\end{array}$ & 0.956 \\
\hline $\begin{array}{l}\text { IQ11 } \\
\text { IQ12 } \\
\text { IQ13 } \\
\text { IQ14 }\end{array}$ & $\begin{array}{r}0.1227 \\
-0.0072 \\
-0.0458 \\
-0.0792\end{array}$ & $\begin{array}{l}0.7003 \\
0.9350 \\
0.9589 \\
0.8869\end{array}$ & $\begin{array}{r}0.3637 \\
0.1281 \\
0.0550 \\
-0.0368\end{array}$ & $\begin{array}{r}0.0205 \\
-0.1467 \\
-0.0517 \\
-0.0038\end{array}$ & $\begin{array}{r}-0.2144 \\
0.0723 \\
0.1193 \\
0.1171\end{array}$ & 0.906 \\
\hline $\begin{array}{l}\text { TQ23 } \\
\text { TQ24 } \\
\text { TQ25 }\end{array}$ & $\begin{array}{l}0.1075 \\
0.1075 \\
0.0478\end{array}$ & $\begin{array}{l}0.1547 \\
0.1547 \\
0.0311\end{array}$ & $\begin{array}{l}0.9355 \\
0.9355 \\
0.9600\end{array}$ & $\begin{array}{r}-0.0020 \\
-0.0020 \\
0.0296\end{array}$ & $\begin{array}{l}0.2059 \\
0.2059 \\
0.0927\end{array}$ & 0.974 \\
\hline $\begin{array}{l}\text { IQ22 } \\
\text { IQ23 }\end{array}$ & $\begin{array}{l}0.1708 \\
0.1456\end{array}$ & $\begin{array}{l}-0.0638 \\
-0.0827\end{array}$ & $\begin{array}{l}0.0165 \\
0.0103\end{array}$ & $\begin{array}{l}0.9752 \\
0.9786\end{array}$ & $\begin{array}{l}0.0322 \\
0.0000\end{array}$ & 0.991 \\
\hline $\begin{array}{l}\text { IQ15 } \\
\text { IQ16 }\end{array}$ & $\begin{array}{l}-0.0953 \\
-0.0760\end{array}$ & $\begin{array}{l}0.1051 \\
0.0365\end{array}$ & $\begin{array}{l}0.2091 \\
0.2006\end{array}$ & $\begin{array}{r}0.0858 \\
-0.0516\end{array}$ & $\begin{array}{l}0.8798 \\
0.8892\end{array}$ & 0.835 \\
\hline \multicolumn{7}{|c|}{ Variance Explained by Each Factor } \\
\hline & 5.03 & 3.34 & 3.02 & 2.06 & 1.80 & \\
\hline
\end{tabular}

Note: Varimax factor rotation is used in the factor analysis. 
TQ23 (There is a clear information privacy policy in place), TQ24 (There are strong regulations and laws governing information sharing), and TQ25 (There is a clear agreement between individuals, companies, and government regarding the use, disclosure, and protection of shared information). E-government leadership is associated with the variables IQ22 (E-government leaders take responsibility for any fraud stemming from e-government development) and IQ23 (Directors, managers, and e-government leaders are held accountable for their actions). Finally, bureaucracy is associated with the variables IQ15 (Directors, managers, and employees avoid sharing information publically in order to protect their current power and interests) and IQ16 (E-government institution leaders have no master plan influencing development of e-government policies, strategy, and law) (see Table 10).

Overall, the average perception score in Table 11 indicates that about $98 \%$ of ICT infrastructure (Factor 1) for the development of e-government shows the challenges to

Table 11. Average Perception Score of Five Key Components of E-Government in Tanzania

\begin{tabular}{|c|c|c|c|}
\hline & Variable & Mean 1 & Mean 2 \\
\hline \multirow{6}{*}{$\begin{array}{c}\text { Factor } 1 \\
\text { (ICT INFRASTRUCTURE) }\end{array}$} & TQ13 & 1.92 & 38.46 \\
\hline & TQ15 & 4.61 & 92.12 \\
\hline & TQ16 & 4.92 & 98.46 \\
\hline & TQ21 & 4.92 & 98.46 \\
\hline & TQ22 & 4.87 & 97.31 \\
\hline & TQ36 & 4.92 & 98.46 \\
\hline \multirow{4}{*}{$\begin{array}{c}\text { Factor } 2 \\
\text { (E-GOV PARTICIPATION \& SUPPORT) }\end{array}$} & IQ11 & 1.28 & 25.58 \\
\hline & IQ12 & 1.46 & 29.23 \\
\hline & IQ13 & 1.41 & 28.27 \\
\hline & IQ14 & 1.35 & 26.92 \\
\hline \multirow{3}{*}{$\begin{array}{c}\text { Factor } 3 \\
\text { (ICT POLICY) }\end{array}$} & TQ23 & 1.75 & 35.00 \\
\hline & TQ24 & 1.75 & 35.00 \\
\hline & TQ25 & 1.69 & 33.85 \\
\hline \multirow{2}{*}{$\begin{array}{c}\text { Factor } 4 \\
(\text { E-GOV LEADERSHIP) }\end{array}$} & IQ22 & 2.26 & 45.19 \\
\hline & IQ23 & 2.20 & 44.04 \\
\hline \multirow{2}{*}{$\begin{array}{c}\text { Factor } 5 \\
\text { (BUREAUCRACY) }\end{array}$} & IQ15 & 4.78 & 95.58 \\
\hline & IQ16 & 4.84 & 96.73 \\
\hline
\end{tabular}

Note: Mean 1 (five point Likert scale); Mean 2 (transformed by 100 scale from Mean 1) 
be lack of an ICT infrastructure master plan, an e-government security policy master plan, an IT master plan, a cyber-security master plan, a data center master plan, and an e-government services master plan. On the other hand, policy instruments and accountability had very low explanatory power $(M=4.78$ and $M=4.84)$ in Tanzania. The absence of policies and accountability in e-government projects generate stumbling blocks for the achievement of the e-government (Heeks, 1998; 2001; 2002). In addition, both Factor 2 (e-government participation support) and Factor 4 (e-government leadership) show very low scores that explain that public servants in e-government institutions are shareholders or business owners in various IT industries in Tanzania $(\mathrm{M}=1.35)$. This attitude has created an environment that is tougher for transforming e-government with transparency and accountability. Meanwhile, $98 \%$ were observed to be stakeholders with others from the private sector who are involved in the egovernment project, and so they tend to take advantage, either by helping their SME's (in the IT industry) or establishing enormous IT companies for maximizing profit rather than focusing on providing quality of service to citizens.

Table 12 suggests that an e-government implementation framework should be developed and recognized. Based on the SWOT analysis, coupled with the technology enactment theory (TET) developed by Fountain (2001), the researchers identified six factors explaining the dogmatism involved in setting up e-government. In order to address this dogmatism, the study analyzed the fear of transparency and accountability, the avalanche of technology, the illusion of innovation and technological misfortune as well as the mix of actors including central and local government, citizens, and other network actors (see Table 12) to examine if they have an important role to play in

Table 12. Proposed E-Government Implementation Framework in Tanzania

\begin{tabular}{c|c|c|c}
\hline & Technology & $\begin{array}{c}\text { Top Down E-Government } \\
\text { (Central Government; } \\
\text { IGO's, Multi-National } \\
\text { cooperation) }\end{array}$ & $\begin{array}{c}\text { Network E-Government } \\
\text { (Governments, IGO's } \\
\text { NGOs, stakeholders, } \\
\text { PPPs, business allies) }\end{array}$ \\
\cline { 2 - 4 } $\begin{array}{c}\text { E-Government } \\
\text { Implementation } \\
\text { in Tanzania }\end{array}$ & $\begin{array}{c}\text { Social } \\
\text { E-Transformation }\end{array}$ & $\begin{array}{c}\text { Bottom-up E-Government } \\
\text { (Local Government; } \\
\text { Citizen, NGOs, PPPs, } \\
\text { Business Allies) }\end{array}$ & $\begin{array}{c}\text { Side-by-Side } \\
\text { E-Government } \\
\text { (IT labs in each ward, } \\
\text { R\&D centers for IT, } \\
\text { NGOs, LGOs and citizens, } \\
\text { governments) }\end{array}$ \\
\cline { 2 - 4 } & $\begin{array}{c}\text { Institutional Docility } \\
\text { (mixed with } \\
\text { technological } \\
\text { and social } \\
\text { e-transformation) }\end{array}$ & $\begin{array}{c}\text { Local E-Government } \\
\text { Governance } \\
\text { (LGOs, elites, markets, } \\
\text { citizens) }\end{array}$ & $\begin{array}{c}\text { National E-Government } \\
\text { Governance } \\
\text { (Governments, LGOs, } \\
\text { elites, citizens, PPPs, } \\
\text { NGOs, IGOs) }\end{array}$ \\
\hline
\end{tabular}


bringing contemporary change in establishing e-government. Contemporary change focused on technology should involve both top-down and networked e-government actors, while social e-transformation should follow a bottom-up and side-by-side egovernment approach, and institutional docility requires a mix of actors coupled with aspects of governance (transparency and accountability) from a local to a national level. This framework may be viewed as interrelated and may sometimes overlap horizontally or vertically. The study recommends that virtuous leadership, along with social etransformation, technology, and addressing institutional docility are necessary for guiding efficient implementation of this structure. It is recommended that these factors play a significant role in all spheres of contemporary change within institutions to achieve effective e-government in Tanzania. The institutions implementing e-government are strongly advised to view this framework as an embryonic dynamic for embracing the e-government transformation in Tanzania.

\section{CONCLUSION: POLICY DIRECTION AND RECOMMENDATIONS}

This study suggests that government institutions, especially the e-government agency and other stakeholders, are struggling to formulate and implement policies for driving e-government transformation and have a perspective diverging from social e-transformation. However, the speed and approaches to this transformation differ significantly due to fear of transparency and accountability, an avalanche of technology, and an illusion of innovation, and problems of technology. To address these differences, this study recommends that e-government institutions intervene within social e-transformation and with other key actors and stakeholder networks to ensure governance from top-down and bottom-up as defined in the proposed e-government implementation framework (Table 12). A strategic e-government plan should not move into the shadow of grievances but rather increase the degree of engagement with social e-transformation, reducing institutional docility to donors with other stakeholders and network actors. In the literature review, Fung (2004: 3) highlighted five strategic e-government goals are: 1) Reinventing government (institutional rearrangement); 2) Delivering integrated electronic services (Institutional docility); 3) Being proactive and responsive (Virtuous Leadership); 4) Using IT and Telecommunications to build a new capability (Technology); and 5) Innovating with IT and Telecommunications. These strategic goals can be appropriately used as a universal policy direction and catalyst for the development of a flourishing environment for e-government in Tanzania.

The SWOT analysis and the factor analysis show the challenges to the policy process 
and suggest involvement of multiple convergent technologies to enable a favorable environment. In general, the Tanzanian ICT policy of 2003, the National Telecommunication Policy of 1997-2020, and the strategic e-government plan of 2012 are not coherently and deeply embedded. They need to be brought together to provide a balanced framework and produce key results-oriented policy. Therefore the implementation of these policy and strategy mixes obscures understanding and effort in transforming the e-government project. It is suggested that Tanzania needs a well-balanced e-government policy deeply-embedded with the underlying value of e-government framework. This must be supplemented with an equal number of telecommunication policy instruments as an axiom to enhance e-government.

Few studies (Heeks, 2002, 2003; Moon, 2004; Havard, 2011) have evidently proven the endurance of virtuous institutional leadership to be important. This study suggests virtuous leadership within e-government institutions in Tanzania to revamp telecommunication policies, broadcasting policies, ICT policies, and strategic e-government plans, and merge related aspects in order to provide effective policy for infrastructure and to design architecture to support full deployment of e-government services in the regions. Moreover, steering IT labs clustered in each area coupled with e-government research and development centers including smart young people, PPP, IT experts, social networks, and government staff is a suggestive approach in Tanzania. This would aid institutions in overcoming the reality of institutional docility coupled with dynamic innovation (see Table 12) to foresight and embraces the capability of egovernment institution. Their prime goals should be towards enabling e-government as an environment conducive to transforming Tanzanian prosperity.

Future research is required to identify potential key variables derived from this research to use as dependent variables in studies of the success of e-government implementation in the Tanzanian context. In addition, information literacy may be a critical factor for sustainable development using e-government (Jung, 2007). Several e-government issues such as the causal relationship between ICT and government performance and citizen perception of various public e-services are still important but have remained systematically unexplored (Park, 2007; Im et al., 2007). Furthermore, it is necessary to look at internet inequality and the e-government transformation process. Lastly, an empirical analysis of utilization of ICT infrastructure should explore whether it has a real causal relationship with e-government strategy for development in the Tanzanian context. The hypothetical question should be whether or not this infrastructure is vital in informing the process of e-government implementation in a broader perspective. Another key area for future research is how to design valid indices for e-government transformation with a focus on challenges and opportunities in developing countries. 


\section{REFERENCES}

Adeyemo, A. 2011. E-government implementation in Nigeria: An assessment of Nigeria's global e-government ranking. Journal of Internet and Information System, 2(1): 11-19.

Akman, K. 2008. Ambiguities of social transformation: A critical framework for the concept. Journal of US-China Public Administration, 5(6): USA (Serial No. 43).

Avgerou, C. 2003. The link between ICT and economic growth in the discourse of development. In Korpela, M., Montealegre, M. \& Poulymenakou, A. (Eds.), International federation of information processing IFIP 9.4 AND 8.2 Joint conference on organizational information systems in the context of globalization. Dordrecht, The Netherlands: Kluwer.

Bhatnagar, S. 2004. E-government from vision to implementation: A practical guide with case studies. New Delhi: Sage.

Castells, M. 2010. The information age: Economy, society and culture volume 1: The rise of the network society. 2nd ed. Oxford: Wiley Blackwell.

Chatwin C. R., \& Pazi, S. M. 2013. Impact of national ICT broadband infrastructure fibre optic backbone (NICTBB) on socio-economic developments in Tanzania, submitted to the Emerald Journal of Systems and Information Technology.

Chaula, J. A. a. Y., Louise \& Kowalski, Stewart. 2006. Technology as a tool for fighting poverty: How culture in the developing world affect the security of information systems. Proceedings of the 4th IEEE international workshop on technology for education in developing countries (TEDC'06).

Choudrie, J., Ghinea, G., \& Weerakkody, V. 2004. Evaluating global e-government sites: A view using web diagnostic tools. Electronic Journal of E-Government, 2(2): 95-104.

Ciampa, M. 2010. Security awareness: Applying practical security in your world. 3rd edition, Engage Learning, Kentucky, USA. ISBN: 978-1-435-45414-9.

Coleman, S. 2006. African e-governance-opportunities and challenges. University of Oxford, Oxford University Press.

Cornford, T., \& Smithson, S. 1997. Project research in information systems: A student's guide. London: Macmillan Press.

Coursey, D., \& Norris D. F. 2008. Models of e-government: Are they correct? An Empirical Assessment. Public Administration Review, 68(3): 523-536.

Dhliwayo, J. 2009. Developing a fiber optic backbone for Africa. Retrieved on January 30, 2015, from www.corning.com/docs/corporate/discovery.../NTR100763.pdf.

DiCaterino, A., \& Pardo, T. A. 1998. The world wide web as a universal interface to government services. Retrieved on January, 10, 2015, from http://www.ctg.albany. 
edu/publications/reports/world_wide_web/world_wide_web_overview.pdf.

Duffy, D. 2000. Q\&A: Balancing the role of e-government: Interview with mike hernon, Vice President of Government for New York City-based GovWorks. Retrieved on January 7, 2015, from Available at: http://www.cnn.com/2000/TECH/computing/ 11/13/qna.egov.idg.

Evans, D., \& Yen, D. C. 2006. Government: Evolving relationship of citizens and government, domestic, and international development. Government Information Quarterly, 2(23): 207-35.

Fountain, J. E. 2001. Building the virtual state: Information technology and institutional change (pp. 155-89). Brookings Institution Press, Washington, DC.

Gil-Garcia, J. R. 2005. Exploring the success factors of state website functionality: An empirical investigation. Proceedings of the international conference on digital government research (Atlanta, Georgia, 2005) (pp. 121-130). Atlanta, Georgia: Digital Government Society of North America.

Grönlund, A. 2005. State of the art in e-government research: Surveying conference publications. International Journal of Electronic Government Research, 1(4): 1-25.

Havard, A. 2007. Virtuous leadership: An agenda for personal excellence. Scepter Publishers, New York.

Heeks, R. 2006. Implementing and managing e-government: An international text. London; Thousand Oaks, Calf: SAGE.

Heeks, R. 1998. Information technology and public sector corruption. Information System and Public Sector Management Working Paper Series, Paper No. 4. Manchester, UK: IDPM, University of Manchester.

Heeks, R. 1999. Reinventing government in the information age: International practice in IT-enabled public sector reform. London, U.K: Routledge.

Heeks, R. 2001. Understanding e-governance for development. The University of Manchester, Institute for Development, Policy and Management Information, Systems, Technology and Government: Working Papers Series, Number 11, 2001. Retrieved on March 22, 2003, from http://idpm.man.ac.uk/idpm/igov11abs.htm.

Heeks, R. 2002. Information systems and developing countries: Failure, success, and local improvisations. The Information Society, 18 (2): 101-12.

Heeks, R. 2003. Most e-government-for-development projects fail: How can risks be reduced? Institute for Development Policy and Management, University of Manchester.

Heeks, R., \& Kenny, C. 2002. ICTs and development. In Krishna, S. \& Madon, S. (Eds.), Proceedings of the 7th International Working Conference of IFIP WG9.4. New Opportunities, Perspectives and Challenges. Bangalore, India.

Ho, T. K. 2002. Reinventing local governments and the e-government initiative. Public 
Administration Review, 62 (4): 434-444.

Hone, K., \& Eloff, J. H. P. 2002. Information security policy - What do international information security standards say? Computers \& Security, 21(5): 402-409.

Im, T. B., Shin, H. Y., Hong, E. Y., \& Jin, Y. K. 2007. Linking theory to evidence: Public policy in the information age: IT and administrative innovation in Korea: How does IT affect organizational performance? Korean Journal of Policy Studies, 21(2): 157-175.

Jung, Kwangho. 2007. Linking theory to evidence: Public policy in the information age: Linking theory to evidence: Public policy in the information age: Literacy skills and schooling from the international adult literacy survey. Korean Journal of Policy Studies, 21(2):177-203.

Karokola, G., \& Yngström, L. 2009. State of e-government development in the developing world: Case of Tanzania_-security view. Proceedings of the ICEG 2009 5th International Conference on e-Government. Boston, USA.

Kumar, V., Mukerji, B., Irfan, B., \& Ajax, P. 2007. Factors for successful e-government adoption: A conceptual framework. The Electronic Journal of e-Government, 5(1): 63-77

Machira, P. 2009. Tanzania needs ICT backbone to survive. Retrieved on February 15, 2015, from http://www.safarilands.org/index.php/news/more/tanzania_needs_ ict_backbone_to_survive/.

Merwe, C. V. 2009. Seacom undersea cable goes live, boosts connectivity. Retrieved on February 18, 2015, from http://www.engineeringnews.co.za/article/seacom -undersea-cable-goes-live-boosts-connectivity-2009-07-23.

Moon, J. 2004. From e-government to m-government? Emerging Practices in the Use of M-Technology by State Governments. IBM Center for the Business of Government.

Mutula, S. M, \& Mostert J. 2010. Challenges and opportunities of e-government in South Africa. The Electronic Library, 28(1): 38-53.

Ndou, V. 2004. E-government for developing countries: Opportunities and challenges. The Electronic Journal of Information Systems in Developing Countries, 1(18): $1-24$.

Ngulube, P. 2007. The nature and accessibility of e-government in sub saharan Africa. International Review of Information Ethics, 7(9): 1-13.

Norris, D. F., \& Moon, M. J. 2005. Advancing e-government at the grassroots: Tortoise or hare? Public Administration Review, 64 (1): 65-75.

Park, J. H. 2007. Linking theory to evidence: Public policy in the information age: How citizens accept e-government service: A comparison of four theoretical models. Korean Journal of Policy Studies, 21(2): 143-156.

Pett, M., Lackey, N., \& Sullivan, J. 2003. Making sense of factor analysis. Thousand 
Oaks: Sage Publications, Inc.

Ritson, N. 2011. Strategic management. USA: Neil Ritson and Ventus Publishing APS.

United Nations e-Government Survey. 2014. E-Government for the Future We Want. New York: United Nations.

United Nations e-Government Survey. 2012. E-Government for People. New York: United Nations.

United Nations/American Society for Public Administration (UN/ASPA). 2002. Benchmarking e-government: A global perspective. Retrieved on October 18, 2002, from http://www.unpan.org/e-Government/Benchmarking\%20E-gov $\% 202001 . p d f$.

Von Solms, B. 2005. Information security governance: COBIT or ISO 17799 or both? Computers \& Security, 24(2): 99-104.

West, D. 2004. E-government and the transformation of service delivery and citizen attitudes. Public Administration Review, 64(1): 15-27.

World Bank. 2005. Definition of e-government. Retrieved on September 11, 2014, from www1.worldbank.org/publicsector/egov/.

Yildiz, M. 2007. E-government research: Reviewing the literature, limitations, and ways forward. Government Information Quarterly, 24(3): 646-665.

Yin, R. 2008. Case study research: Design and methods (4th Edition). London: Sage Publications.

Yonazi, J. J. 2010. Enhancing adoption of e-government initiatives in Tanzania. Groningen, The Netherlands: University of Groningen. 
Appendix 1. Analysis of the Demographic Profile of the Respondents $(N=104)$

\begin{tabular}{|c|c|c|c|}
\hline \multicolumn{2}{|c|}{ Variables } & Frequency & Percent \\
\hline \multirow{2}{*}{ Gender } & Female & 68 & 65.4 \\
\hline & Male & 36 & 34.6 \\
\hline \multirow{4}{*}{ Age } & 20-30 Years & 23 & 22.1 \\
\hline & $31-40$ Years & 35 & 33.7 \\
\hline & 41-50 Years & 28 & 26.9 \\
\hline & 51 and above & 18 & 17.3 \\
\hline \multirow{6}{*}{ Education } & Basic Education & 5 & 4.8 \\
\hline & Diploma & 1 & 1.0 \\
\hline & Advanced Diploma & 5 & 4.8 \\
\hline & Bachelor's Degree & 38 & 36.5 \\
\hline & Master's Degree & 43 & 41.3 \\
\hline & Ph.D. & 12 & 11.5 \\
\hline \multirow{5}{*}{ Survey Respondent Area } & Government institutions & 37 & 35.6 \\
\hline & Private institutions & 17 & 16.3 \\
\hline & Social forums & 18 & 17.3 \\
\hline & Educational Institutions & 22 & 21.2 \\
\hline & Entrepreneurship & 10 & 9.6 \\
\hline
\end{tabular}


Appendix 2. Frequency Distribution of the Target Population $(\mathrm{N}=104)$

\begin{tabular}{l|c|c|c}
\hline & Frequency & Percent & Cumulative Percent \\
\hline e-government Agency & 9 & 8.7 & 8.7 \\
\hline Ministry of Communication, science and Tech & 4 & 3.8 & 12.5 \\
\hline Ministry of Finance & 4 & 3.8 & 16.3 \\
\hline Ministry of Justices & 5 & 4.8 & 21.2 \\
\hline Ministry of Home Affairs & 4 & 3.8 & 25.0 \\
\hline Prime Ministers Offices & 5 & 4.8 & 29.8 \\
\hline President Office - PSM & 6 & 5.8 & 35.6 \\
\hline Airtel & 5 & 4.8 & 40.4 \\
\hline Tigo & 3 & 2.9 & 43.3 \\
\hline Vodacom & 5 & 4.8 & 48.1 \\
\hline Zantel & 4 & 3.8 & 51.9 \\
\hline Ethinktan & 10 & 9.6 & 61.5 \\
\hline Wanabidii & 8 & 7.7 & 69.2 \\
\hline Sihebs & 4 & 3.8 & 73.1 \\
\hline E4E technologies & 4 & 3.8 & 76.9 \\
\hline Vinjari website & 2 & 1.9 & 78.8 \\
\hline Tumaini University & 10 & 9.6 & 88.5 \\
\hline Nelson Mandela & 6 & 5.8 & 94.2 \\
\hline St. Augustine University & 6.8 & 100.0 \\
\hline
\end{tabular}


Appendix 3. Frequency Distribution of the Basic Categories of the Target Population $(N=104)$

\begin{tabular}{l|c|c|c}
\hline & Frequency & Percent & Cumulative Percent \\
\hline CEO & 5 & 4.8 & 4.8 \\
\hline Managing Director - MD & 1 & 1.0 & 5.8 \\
\hline Director & 40 & 38.5 & 44.2 \\
\hline Manager & 10 & 9.6 & 53.8 \\
\hline Business Manager & 1 & 1.0 & 54.8 \\
\hline Chief Officer & 4 & 3.8 & 58.7 \\
\hline Senior Legal Officer & 5 & 4.8 & 63.5 \\
\hline IT & 5 & 4.8 & 68.3 \\
\hline Software Developer & 6 & 5.8 & 74.0 \\
\hline Security experts & 7 & 6.7 & 80.8 \\
\hline Lecturers & 9 & 8.7 & 89.4 \\
\hline Tutorial Assistance & 11 & 10.6 & 100.0 \\
\hline
\end{tabular}

